\title{
Gender and Equality in Muslim Family Law, Justice, and Ethics in the Islamic Legal Tradition
}

\author{
Ziba Mir-Hosseini, Kari Vogt, Lena Larsen, and Christian Moe, eds. \\ New York: I.B. Tauris, 2013. 320 pages.
}

In the aftermath of the Arab Spring, some advocated a turn toward "tradition," thereby raising fears that women would be pushed out of the public arena despite their active participation and would even lose those gains made under previous governments. The debates around gender parity vs. complementarity that were stirred up were not new, but they did manage to acquire new cogency in the context of the emotionally charged deconstruction of the old political system and the subsequent transition to new governments.

The arguments made by both sides were often couched within a framework of liberal human rights or in terms of Islamic tradition. Gender and Equality in Muslim Family Law is a valuable contribution to the discussion on the apparent contradiction between these discourses and a learned attempt to bridge them. The editors of this collective book, which stems from a number of workshops organized by the Oslo Coalition on Freedom of Religion or Belief, explore how gender equality, as shaped by contemporary ideas of human rights, can be reconciled with the Islamic legal tradition, which is rooted in pre-modern conceptions of justice.

In the first chapter, Mir-Hosseini examines the classical fiqhī understanding of gender justice by focusing on qiwämah (guardianship of women), which is enshrined in most Muslim family codes, and overviews twentieth-century reforms and codifications. She also discusses the ideas of al-Tahir al-Haddad (d. 1935) and Fazlur Rahman (d. 1988), two reformists who influenced subsequent discourses on equality in the family within an Islamic framework. Her contribution ends with a looks at the emergence of political Islam, transnational feminism, and non-governmental organizations (NGOs), all of which add a new dimension to preexisting debates.

The rest of the book is divided into two sections. The first explores some concrete efforts at legal reform and social activism that reconcile Islam and human rights. Mulki al-Sharmani delves into the concept of qiwämah in Egyptian law and in courtroom practice, pointing out the legal strategies pursued by litigants and the disconnect between the model of marriage upheld by family codes and the actual practice of marriage. Marwa Sharafedin analyzes Egyptian women's rights NGOs and their discourse on personal status law that blend, to varying degrees, religious and human rights frames 
of reference. Aicha El Hajjami delves into the religious arguments used during the 2004 debate on reforming the Moroccan family code. While stressing the legal and discursive innovations introduced, she observes that the judiciary's resistance, lacunas in the text, and social pressure hinder the new code's enforcement.

Zainah Anwar recounts how Malaysia's SIS (Sisters in Islam) spread its activities into new practical and theoretical fields under the dual pressure of Islamist attempts to turn the country into an Islamic state and state-led Islamization. SIS increasingly moved to hermeneutical discourses, public education, and legal training, until in 2009 the global movement Musawah was launched there and came to constitute a space of interaction between different strategies to advance women's rights. This new group has helped bridge the gap between a human rights discourse and an Islamic discourse.

The second section deconstructs traditionalist approaches to gender roles and discusses theoretical approaches that allow for gender equality to be supported from within Islam. In his analysis of the classical understanding of wiläyah (marriage guardianship), Muhammad Khalid Masud underscores the diverse juridical views and how particular social contexts informed the doctrine. He then studies gender equality in the thought of several intellectuals who have offered new hermeneutical approaches. In the following chapter, Nasr Abu Zayd (d. 2010) expresses his view on how to read the Qur'an by "defragmenting" its polyphonic discourse and proposes a new contextual ijtihād to gender issues in legal matters by using inheritance and qiwāmah as examples. Faqihuddin Abdoul Kodir focuses on the Hadith literature, which has received far less attention from reformists, despite its importance in shaping figh. He suggests a contextual reading of the Prophetic traditions, one informed by Islam's ethical principles, using qiwämah and that of women travelling without a male relative as examples.

Hassan Yousefi Eshkevari, who focuses on and then refutes the sociological, historical, and epistemological assumptions of qiwāmah and wilāyah, submits ways to rethink women's rights in the Islamic legal tradition by taking into account a contemporary understanding of justice: The time has come, he writes, for a "fundamental shake-up" (p. 209) based on the revision of theoretical assumptions and an awareness of their relationship with social circumstances. Mohsen Kadivar reviews the rational and textual arguments for a "deserts-based justice," which has led to unequal gender rights, and for egalitarian justice, which he considers more in accord with "contemporary rationality" (p. 231) and with the spirit of the Qur'an. Desert-based justice, he argues, was a first step to equality within a divine strategy of gradualism, 
rather than a set of immutable rules. The Qur'anic verses and hadiths invoked to justify legal differences should be reread in the light of what appears to us today "just, reasonable, ethical and superior" (p. 231).

The second section's essays ponder how to take into account factual difference while respecting equality, a central issue in Anver M. Emon's concluding chapter. Emon discusses how gender difference has justified differentiation and led to discrimination in traditional Islam. He then presents examples of contemporary reformists to point out that how ignoring "the paradox of equality" limits the effectiveness of their arguments. The importance of this paradox points out that understanding how factual difference has resulted in unequal rights requires a comprehensive understanding of the context in which legal rules were elaborated. He coherently concludes by arguing that legal changes involve "significant reformulations of socially and culturally embedded ideas about the right and wrong" (p. 251) and thus require broader societal and political change.

This leads me to a criticism: In this book, the social and political constraints to reform referred to in passing by most authors might have merited greater attention. The mention of political issues, such as those pertaining to the pressure applied by other countries to resist or advance reform in conformity with geostrategic and economic interests, would have helped readers grasp why there is such an enormous amount of resistance in the Muslim world to reforming hermeneutics. Another issue that may have merited greater attention instead of just a brief mention in Al Sharmani's essay is that of courtroom practice, as some Muslim judges have advanced in innovative ways a holistic approach to gender rights that blends human rights and Islam, thereby contributing to wider debates and doctrinal developments.

These considerations aside, the book is a valuable resource for those interested in gender and Islam and in understanding current reformist ideas. The first section, although somewhat limited in its geographical focus, offers stimulating insights; the second, by focusing on the often overlooked underlying values and assumptions of traditional Islam, is an especially valuable contribution. All essays are well referenced and rely on either primary sources or fieldwork. A detailed index is provided at the end of the book.

Elisa Ada Giunchi Dipartimento di Studi Internazionali, giuridici e storico-politici Università degli studi di Milano, Milan, Italy 